Bazyli DEGÓRSKI O.S.P.P.E.

(Rzym, Angelicum)

\title{
WDOWY W STAROŻYTNOŚCI CHRZEŚCIJAŃSKIEJ I ICH POSŁUGA W KOŚCIELE
}

Niniejszy artykuł pragnie przybliżyć czytelnikowi polskiemu zagadnienie spelniania przez wdowy w starożytnym Kościele posług liturgiczno-służebnych. Tematyka ta jest niewątpliwie ważna ze względu choćby na pojawiających się także i w naszym Kościele zwolenników udzielania kobietom święceń (jeżeli nie kapłańskich, to przynajmniej diakońskich). Warto więc przyjrzeć się, jak przedstawiało się to zagadnienie w Kościele starożytnym, znajdującym się u źródeł czystej tradycji apostolskiej. W artykule będziemy się opierali wyłącznie na analizie źródeł okresu patrystycznego, przekazujących wiadomości na interesujący nas temat. Trzymać się tu będziemy schematu chronologiczno-geograficznego, poczynając od dokumentów najstarszych, przedstawiających tradycję wschodnią, aby z kolei przejść stopniowo na teren Kościoła Zachodniego.

1. Poshuga wdów w II i III wieku. Już w najstarszych pismach chrześcijańskich okresu poapostolskiego II wieku często spotykamy wzmianki dotyczące szczególnej, uprzywilejowanej przez Kościół kategorii kobiet - wdów. Wdowy jednak nie jawią się w tym czasie zasadniczo jako spełniające jakąś konkretną posługę liturgiczną wewnątrz wspólnoty kościelnej, lecz bywają wzmiankowane jako osoby, które powinny być otaczane przez duszpasterzy i wiernych specjalną troską, gdyż stanowią wraz z biednymi i sierotami uprzywilejowaną cząstkę Kościoła, z którą utożsamil się sam Jezus Chrystus. Słowo «wdowa» staje się jednak już i w tym okresie terminem technicznym, określającym także szczególny stan życia duchowego, odznaczający się praktykowaniem cnoty czystości, ducha pokuty i umartwienia oraz gorliwej modlitwy ${ }^{1}$. Św. Ignacy Antiocheński, pisząc do mieszkańców Smyrny, na końcu listu kieruje do wdów szczególne pozdrowienie:

${ }^{1}$ Por. B. Degórski, Liturgiczna postuga kobiet w Kościele pierwszych wieków, „Dissertationes Paulinorum" 7 (1994) 20. 
„Pozdrawiam rodziny moich braci wraz z żonami i dziećmi, oraz dziewice zwane wdowami. Bądźcie silni mocą Ducha!"2

Znamy także dwa inne teksty, pochodzące z II wieku, które mówią o kobietach spelniajacych pewne posługi liturgiczno-apostolskie. Pierwszy znajduje się w Pasterzu Hermasa. Posługując się językiem apokaliptyki, przedstawia on starą niewiastę, symbolizującą Kościół, która prosi Hermasa, aby przekazał jedną z ksiąg objawienia kobiecie imieniem Grapte, by ta $\mathrm{z}$ kolei odczytala ją sierotom i wdowom powierzonym jej trosce:

„[...] doznałem widzenia w moim domu. Otóź przyszła staruszka i spytala mnie, czy dałem księgę prezbiterom. Powiedziałem, iż nie dałem jej. «Dobrze zrobiłeś odrzekła - gdyż muszę dodać pewne slowa. Gdy umieszczę wszystkie słowa, dasz je poznać wszystkim wybranym. Napiszesz dwie książeczki i prześlesz jedną Klemensowi, a drugą Grapte. Klemens prześle ją następnie innym miastom, jak został do tego zobowiązany. Grapte zaś zachęci wdowy i sieroty. Ty natomiast przeczytasz ją temuż miastu wraz z prezbiterami, którzy przewodzą Kościołom»"3.

Te świadectwa stanowią właściwie jedyne dwa najstarsze pisma, które wspominają kobiety wykonujące jakieś posługi duszpastersko-katechetycznoliturgiczne.

Wychođząc poza okres Ojców Apostolskich, spotykamy świadectwo Tertuliana, będące odbiciem sytuacji w łacińskiej Afryce Pólnocnej końca II wieku. Z pism tego Kartagińczyka wynika, iż w owym czasie istniała szczególna kategoria wdów, która we wspólnocie kościelnej stanowiła pewnego rodzaju ordo, istniejące obok męskiej hierarchii, złożonej $\mathrm{z}$ biskupa, kapłanów i diakonów. Wdowy te między innymi miały za zadanie udzielać porad związanych z zawieraniem małżeństwa. Opierając się na tej ich funkcji, Afrykańczyk który był już wówczas montanistą i jako taki głosił bardzo surowe zasady moralno-ascetyczne - starał się dostarczyć dowodów, że powtórnie zawarte małżeństwo (po śmierci jednego $\mathrm{z}$ małżonków) jest niegodne chrześcijanina, gdyż jest zwykłym, zakamuflowanym cudzołóstwem:

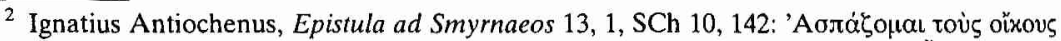

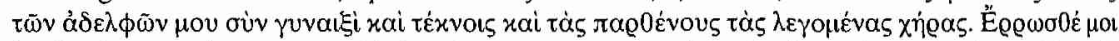

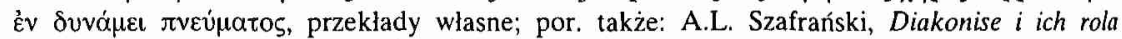
w pierwotnym Kościele, VoxP 9 (1989) 738.

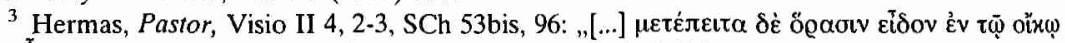

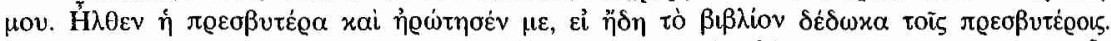

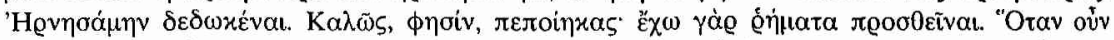

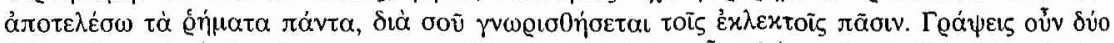

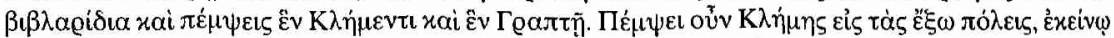

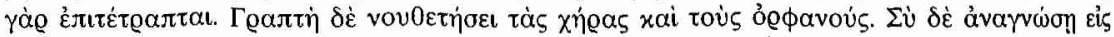

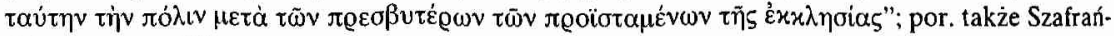
ski, art. cyt., s. 739. 
„Jakim prawem ośmielasz się prosić o zawarcie małżeństwa, które przecież jest zabronione tym, których o to prosisz: biskup może być żonatym tylko jeden raz, prezbiterzy podlegają temu samemu prawu, także i wdowy, których sposób życia odrzucileś poprzez swoje postępowanie?"

Jak gdzie indziej zaświadcza Tertulian, właśnie u wdów pokutnicy - czyli osoby, które popełniły grzech ciężki (zaparły się wiary, dopuściły się cudzołóstwa lub zabójstwa) - szukali wstawiennictwa, aby rychlej uzyskał dopuszczenie do wspólnoty wiernych i uczestniczył w życiu sakramentalnym5 ${ }^{5}$. Afrykańczyk nie mówi jednak nic na temat ich ewentualnej posługi liturgicznej. Z jego dzieła De virginibus velandis dowiadujemy się natomiast, że we wspólnocie kościelnej istniała szczególna kategoria kobiet, która tworzyła swoistego rodzaju ordo viduarum:

„Bardzo dobrze wiem, że w pewnym miejscu dziewica, która nie osiągnęła jeszcze dwudziestu lat, została oficjalnie dopuszczona do stanu wdów. Jeżeli nawet biskup chcial dostarczyć jej jakiejś pomocy, to mógł niewątpliwie uczynić to w inny sposób, zachowując szacunek względem praktyki kościelnej. W ten to bowiem sposób w Kościele nie miałoby teraz miejsca to zniesławienie spowodowane tego rodzaju cudactwem - żeby nie powiedzieć «ohydą» - to znaczy obecnością dziewicy wdowy. Jeszcze więksszy zgrzyt powoduje fakt, iż - uchodząc za wdowę - nie nakrywa ona sobie glowy welonem. W ten to sposób pokazuje, że nie jest ani jedną, ani drugą: nie jest dziewica, gdyż uchodzi za wdowę i nie jest wdową, gdyż zachowuje się jak dziewica. Na mocy jednak uprawnień otrzymanych od biskupa zasiada ona wśród wdów z odkrytą głową, ponieważ jest także dziewicą. Aby móc zasiadać na tym miejscu - oprócz faktu, iż wymagany jest wiek sześćdziesięciu lat (por. $1 \mathrm{Tm} 5,9$ ) zostają niekiedy wybrane nie tylko te kobiety, które miały jednego mężczyznę, a więc te, które wyszły za mąż, lecz także i matki, które - co więcej - wychowały swoje dzieci (por. 1Tm 5,10). Oczywiście, będąc kobietami, które doświadczyły wszelkiego rodzaju uczuć, latwo będą mogły pomóc innym czy to przez swoje rady, czy przez pocieszające wsparcie, gdyż doświadczyły one przynajmniej tych wszystkich sytuacji, w których kobieta może jawić się jako godna pochwały. Oto dlaczego dziewice nie mają żadnej możności, aby wykazać swoją brawurę w tym względzie"6.

${ }^{4}$ De monogamia 11, 1, CCL 2, 1244: ,[...] qualis es id matrimonium postulans quod eis a quibus postulas non licet habere, ab episcopo monogamo, a presbyteris et diaconis eiusdem sacramenti a viduis, quarum sectam in te recusasti?".

${ }^{5}$ Por. De pudicitia 13, 7, CCL 2, 1304: „Et tu quidem paenitentiam moechi ad exorandam fraternitatem in ecclesiam inducens conciliatum et concineratum cum dedecore et horrore compositum prosternis in medium ante viduas, ante presbyteros, omnium lacrimas suadentem, omnium vestigia lambentem, omnium genua detinentem".

${ }^{6}$ De virginibus velandis $9,2-3, \mathrm{CCL} 2,1219$ : „Plane scio alicubi virginem in viduatu ab annis nondum viginti collocatam. Cui si quid refrigerii debuerat episcopus, aliter utique salvo respectu disciplinae praestare potuisset, ne tale nunc miraculum, ne dixerim monstrum, in ecclesia denotaretur, virgo vidua, hoc quidem portentuasior, quod nec qua vidua caput texit, utrumque se negans, et virginem, quae vidua deputetur, et viduam, quae virgo dicatur. Sed ea auctoritate illic sedet intecta qua et virgo, ad quam sedem praeter annos sexaginta non tantum univirae, id est nuptae, aliquando eliguntur, sed et matres, et quidem educatrices filiorum, scilicet ut experimentis omnium affectuum 
Jak wynika z powyższego fragmentu, niewiasta, która chce zostać dopuszczona do ordo viduarum, powinna odpowiadać wymogom ustalonym w $1 \mathrm{Tm} 5$, 9-10, to znaczy: mieć przynajmniej sześćdziesiąt lat, być zamężną tylko jeden raz, oraz szczycić się dobrym wychowaniem swoich dzieci. Dopuszczenie zaś do tegoż ordo zależy od samego biskupa.

Podobne zasady spotykamy w zbiorze przepisów liturgiczno-kanonicznych Traditio Apostolica św. Hipolita Rzymskiego:

\begin{abstract}
„Wdowa, podczas swojego ustanawiania, nie bywa wyświęcana, lecz zostaje wybrana, aby cieszyć się tym mianem. Może zostać ustanowioną, jeśli jej mąż nie żyje już od dłuższego czasu. Jeśli jednak jej mąż umarl niedawno, nie należy jej ufać, lecz dopiero, gdy się zestarzeje, niech zostanie zatwierdzona na pewien okres czasu. [...]. Niech zostanie ustanowiona wdowa jedynie poprzez wypowiedzenie [odpowiednich] stów i niech [w ten sposób] zostanie dołączona do grona pozostałych [wdów]. Niech nie wkłada się na nią ręki, gdyż nie składa ona ofiary i nie sprawuje liturgii. Święcenia zaś bywają udzielane tylko duchownym ze względu na sprawowanie liturgii. Wdowa natomiast bywa ustanawianą ze względu na modlitwę, tę zaś mają spełniać wszyscy"7.
\end{abstract}

Jak widać $\mathrm{z}$ powyższego urywku, wdowy nie mają spełniać $\mathrm{w}$ Kościele żadnej posługi liturgicznej, gdyż nie przyjmują specjalnych święceń udzielanych poprzez włożenie rąk, jak ma to miejsce w przypadku duchownych męzczyzn, którzy sprawuja posługi liturgiczne. Niektóre $z$ wdów bywają jedynie ustanawiane, aby w ten sposób móc należeć do specjalnej grupy kobiet „wdów", których głównym zadaniem jest modlitwa, będąca jednak - jak to podkreśla sam tekst - obowiązkiem wszystkich wiernych.

Należy powiedzieć, że taka była stała i niezmienna praktyka całego Wielkiego, prawowiernego Kościoła starożytności chrześcijańskiej. Jeżeli jednak chodzi w tym względzie o grupy błędnowiercze, które nie należały do Wielkiego Kościoła, to sprawa przedstawia się zgoła inaczej. Widzimy tu bowiem choćby kobiety spełniające posługę głoszenia slowa Bożego, działające na równi z samymi Apostołami ${ }^{8}$.

structurae et facile norint ceteras et consilio et solatio iuvare, et ut nihilominus ea decucurrerint per quae femina probari potest. Adeo nihil virgini ad honorem de loco permissum est".

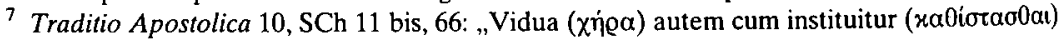
non ordinatur ( $\chi$ clootoveiv) sed eligitur ex nomine. Si autem vir eius mortuus est a tempore magno, instituatur ( $(\alpha \alpha \theta i \sigma \tau \alpha \sigma \theta \alpha$ ) . Si autem non post multum tempus mortuus est vir eius, non confidatur

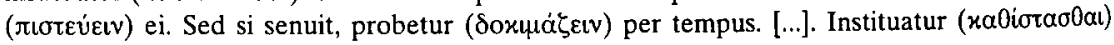
vidua $(\chi \eta \dot{\eta} \varrho \alpha)$ per verbum tantum et se iungat cum reliquo. Non autem imponetur manus super

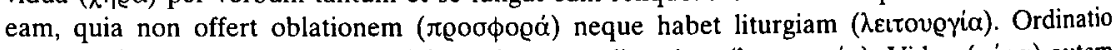

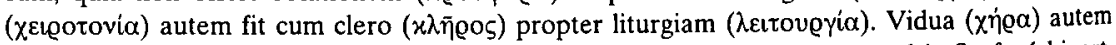

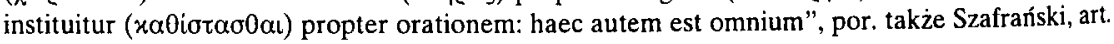
cyt., s. 740.

${ }^{8}$ Dla przykladu, apokryficzne Dzieje apostoła Filipa wspominaja jego siostrę - Mariamne, która zostaje wybrana przez samego Chrystusa, aby być współpracowniczką działalności ewange- 
2. Wdowy wedlug dokumentów Syrii Wschodniej. Pierwszym dokumentem, który mówi o diakonisach na terenach Syrii Wschodniej jest Didascalia Apostolorum. Został on napisany po grecku prawdopodobnie w pierwszej połowie III wieku w kręgach pozostających pod wpływem Antiochii Syryjskiej. ${ }^{9}$ Oryginał grecki nie dochował się jednak do naszych czasów. Znamy go tylko dzięki starożytnym thumaczeniom sporządzonym w języku syryjskim, etiopskim, arabskim i częściowo łacińskim ${ }^{10}$.

Jeżeli chodzi o kobiety jako takie, Didascalia Apostolorum wspomina często zwykłe wdowy, które nie stanowią jednak jakiejś szczególnej kategorii wśród struktur kościelnych. Nie posiadając męża, a więc będąc biednymi i wystawionymi na różne niebezpieczeństwa życiowe, wdowy - na równi $\mathrm{z}$ innymi tego rodzaju kategoriami społecznymi (biedni jako tacy, cudzoziemcy, sieroty, itp.) - winny stanowić przedmiot szczególnej troski biskupa ${ }^{11}$. Także i wierni mają obowiązek wspierania ich poprzez różne dary, jak to miało miejsce w Starym Przymierzu w stosunku do lewitów ${ }^{12}$.

Didascalia mówi jednak także o wdowach, które tworzą ordo viduarum. Aby do niego móc należeć, wdowa powinna mieć ukończone przynajmniej pięćdziesiąt lat, i nie mogła już wychodzić za mąż po raz wtóry ${ }^{13}$. Jej zadaniem miała być wyłącznie modlitwa za Kościól i za jego dobrodziejów ${ }^{14}$. Dokument wyklucza wprost możliwość udzielania przez nie sakramentu chrztu, co może wskazywać, iż praktyka taka istniała, lub że przynajmniej domagano się tego lub brano pod uwagę. W argumentacji Didascalia powołuje się tu na przykład samego Jezusa, uważając przez to chrzest udzielany przez kobiety za czyn przeciwny nauce Ewangelii i jako taki wielce szkodliwy zarówno dla szafarki jak i dla osoby przyjmującej go:

„Nie zalecamy ani, by kobieta chrzciła, ani by ktokolwiek przyjmowal chrzest od kobiety, gdyż jest to przekroczeniem przykazania i stanowi wielkie niebezpieczeństwo dla tego, kto jest chrzczony, i dla tej, która chrzci. Jeżeli byłoby rzeczą godziwą przyjmować chrzest od kobiety, to nasz Mistrz zostalby ochrzczony przez Maryję, swoją Matkę. Przyjął on jednak chrzest od Jana, jak i inne osoby z ludu. Nie narażajcie się więc, bracia i siostry, na niebezpieczeństwo, postępując wbrew prawu Ewangelii!"15.

lizacyjnej swojego brata, por. Acta Philippi 8, 94-95, ed. M. Bonnet: Acta Apostolorum Apocrypha, II/2, Lipsiae 1959, 36-37.

9 Odnośnie do daty powstania tego dokumentu por. P. Galtier, La date de la Didascalie des apôtres, RHE 42 (1947) 315-351; P. Nautin, Didascalia degli Apostoli; DPAC I 949.

${ }^{10}$ Por. Degórski, Liturgiczna posíuga kobiet..., art. cyt., s. 30-31.

${ }^{11}$ Por. Didascalia Apostolorum II 4, 1.

${ }^{12}$ Por. tamze, II 26, 1-3.

13 Por. tamże, III $1,1$.

14 Por. tamże, III 5, 2.

${ }^{15}$ Tamże, III 9, 1-3, ed. F.X. Funk: Didascalia et Constitutiones Apostolorum, I, Paderbornae 1905, 198-200: „Mulierem aut baptizare vel a muliere baptizari non approbamus, quia hoc illegi- 
Co więcej, dokument zakazuje wdowom także zwykłego nauczania, powołując się również na przykład samego Jezusa Chrystusa, który nie wybrał kobiet do głoszenia Ewangelii, aczkolwiek otaczały Go i obsługiwały:

„Nie jest rzeczą odpowiednią ani konieczną, aby kobiety nauczały szczególnie tego, co odnosi się do imienia Chrystusa i do odkupienia poprzez mękę. Wy bowiem nie zostałyście ustanowione - wy, kobiety, a szczególnie wy, wdowy - po to, aby nauczać, lecz po to, aby modlić się i błagać Pana Boga. Pan Bóg bowiem Jezus Chrystus, nasz Mistrz, posłał nas - Dwunastu - aby nauczać lud i pogan. Były z nami uczennice kobiety - Maria Magdalena, Maria córka Jakuba i inna Maria, lecz nie posłal ich, aby wraz z nami nauczały lud. Jeżeli zaś byłoby konieczne, aby kobiety nauczały, to sam nasz Mistrz zarządziłby, aby i one wraz z nami to czynity"16.

3. Wdowy w monofizyckim Kościele Syrii. O wdowach dowiadujemy się również z dokumentu zatytułowanego Testamentum Domini nostri Iesu Christi, który zostal napisany w V wieku w Syrii w środowisku monofizyckim. Jest to traktat kanoniczno-liturgiczny, który zachowal się w języku syryjskim, arabskim i etiopskim ${ }^{17}$. Wydał go I. Rahmani jedynie w wersji syryjskiej $z$ jej lacińskim thumaczeniem ${ }^{18}$. Sam dokument chce być słowami testamentu zmartwychwstałego Pana, spisanymi przez apostołów. W rzeczy jednak samej jego tekst ma swe źródło w omówionej przez nas Traditio Apostolica św. Hipolita Rzymskiego.

Odnośnie do posług kobiecych w Kościele, w Testamentum Domini nostri lesu Christi spotykamy najpierw przepisy dotyczące wdów. Są one o wiele dłuższe niż w Traditio Apostolica: bo obejmują aż cztery rozdziały, podczas gdy u Hipolita poświęcono im tylko jeden rozdzial ${ }^{19}$. Wdowy wedhu Testamentum Domini nostri lesu Christi wymieniane są jako stanowiące - wraz z prezbiterami, diakonami i subdiakonami - strukturę hierarchii kościelnej:

timum est et magnum periculum ei, quae baptizat, et ei, qui baptizatur. Si enim liceret a muliere baptizari, profecto Dominus ac magister noster a Maria matre sua baptizatus fuisset; baptizatus est autem a Ioanne, sicut et alii e populo. Nolite igitur vobis periculum struere, fratres et sorores, conversantes praeter legem evangelii”; por. także Szafraníski, art. cyt., s. 743.

${ }^{16}$ Tamże, III 6, 1-2, ed. Funk s. 190 : „Non decet ergo neque necessarium est, ut mulieres doceant, et praesertim de nomine Christi et de redemptione passionis eius. Nam non ad hoc estis constitutae, ut doceatis, o mulieres ac maxime viduae, sed ut oretis ac rogetis Dominum Deum, quia Dominus Deus Iesus Christus magister noster nos duodecim misit, ut doceamus populum et gentes; erant enim nobiscum discipulae Maria Magdalene et Maria filia Iacobi et altera Maria, neque emisit, ut nobiscum populum doceant. Si enim necesse fuisset, ut mulieres docerent, magister noster has ipsas iussisset nobiscum docere".

17 Por. Degórski, Liturgiczna postuga kobiet..., art. cyt., s. 34.

18 Por. I. Rahmani: Testamentum Domini nostri lesu Christi, Moguntiae 1899.

19 Por. rozdzial 10. 
„W Kościele niech będzie dwunastu prezbiterów, siedmiu diakonów, czternastu subdiakonów. Wdów zaś, które cieszą się pierwszeństwem w zasiadaniu, niech będzie trzynaście" 20 .

Nie chodzi tu więc o zwykłe wdowy, które straciły męża, lecz o szczególny rodzaj kobiet, ,które cieszą się pierwszeństwem” w stosunku do innych kobiet i mężczyzn, którzy nie są duchownymi. Aby móc należeć do tego rodzaju grupy wdów, trzeba zostać oficjalnie ,wybraną", to znaczy - oficjalnie dopuszczoną po dokładnym zbadaniu całej sprawy, opierając się także na opinii wiernych. Warunkiem do tego, aby została ,wybraną", jest pozostawanie bez męża przez dlugi okres czasu. Chodzi o to, aby spelniająca posługę kościelną wdowa była osobą zupełnie wolną i ustabilizowaną życiowo. $Z$ tego więc powodu Testamentum Domini nostri Iesu Christi dodaje, że może być wybraną tylko taka wdowa, o której rękę prosiło wielu mężczyzn, nie osiągnąwszy jednak zamierzonego skutku ${ }^{21}$.

Wdowę uroczyście święci biskup, który wymawia nad nią odpowiednią modlitwę, podczas gdy ona sam w pokorze, ze spuszczonymi oczyma, modli się u wejścia do prezbiterium. W modlitwie biskup wyprasza dla święconej siłę do radosnego wypełniania zadań, które ma spełniać, oraz moc potrzebną do dźwigania ciężaru, który zapragnęła nieść ${ }^{22}$.

„Wybrane” i ustanowione uroczyście przez wspólnotę kościelną wdowy podczas sprawowania liturgii są obecne $w$ prezbiterium wraz $z$ czlonkami innych stopni hierarchii. Pośrodku nich stoi biskup otoczony $\mathrm{z}$ dwóch stron gronem prezbiterów. Po ich zaś prawej stronie znajdują się diakoni, a po lewej - wdowy. Oprócz nich - jako mający niższą rangę i spełniający niższe posługi zajmują miejsca lektorzy i subdiakoni ${ }^{23}$. Wyższa ranga wdów względem lektorów i subdiakonów wyraża się także przez to, iż przyjmują one komunię wcześniej on nich, to znaczy: zaraz po diakonach ${ }^{24}$.

Jeżeli chodzi o zadania duszpasterskie wdów, to ograniczają się one do posługi względem kobiet. Przede wszystkim dotyczą katechizowania niewiast

${ }^{20}$ Testamentum Domini nostri Iesu Christi 1, 34, 4, ed. Rahmani s. 83: „In ecclesia noti sint duodecim presbyteri, septem diaconi, quatuor hypodiaconi et tres viduae habentes praecedentiam sessionis".

${ }^{21}$ Por. tamże I 40, 1, ed. Rahmani s. 95: „Ordinetur in viduam illa, quae eligitur, quae scilicet diuturno tempore sine viro manserit, pluriesque ab hominibus inducta fuerit, ut nuberet viro et nihilominus ipsa viro adhaerere noluerit propter fidem"; por. także Szafrański, art. cyt., s. 747.

22 Por. Testamentum Domini nostri Iesu Christi 1, 41.

${ }^{23}$ Por. tamże I 23, 1, ed. Rahmani s. 35-37: „[Episcopus] offerat intra velum una cum presbyteris, diaconis, viduis canonicis, hypodiaconis, diaconissis, lectoribus et habentibus charismata".

${ }^{24}$ Por. tamże I 23, ed. Rahmani s. 35-37: „Primus in medio consistat episcopus, et post ipsum immediate sistant presbyteri hinc et inde, et post presbyteros, qui sunt in parte sinistra, sequantur proxime viduae, post presbyteros, qui sunt in parte dextera, stent diaconi, et post hos lectores, et post lectores hypodiaconi, et post hypodiaconos diaconissae". 
przygotowujących się do przyjścia sakramentu chrztu świętego, pouczania i uświadamiania niewykształconych, opieki nad dziewicami, które postanowity prowadzić tego rodzaju sposób życia ze względu na królestwo Boże (powinny nawet starać się organizować dla nich spotkania i wraz z nimi modlić się). Ponadto mają odwiedzać chore kobiety i starać się pouczać i nawracać te, które żyją źle ${ }^{25}$. Jeżeli zaś chodzi o posługę wdów związaną z sakramentami, to ogranicza się ona do pilnowania, aby wchodzące do świątyni kobiety zachowywały się w odpowiedni sposób $b^{26}$ i do namaszczania niewiast olejem podczas udzielania chrztu i troski o zasłanianie podczas chrztu welonem nagości kobiety przed wzrokiem biskupa $^{27}$.

4. Posługiwanie wdów w Kościele kręgu kultury greckiej. Ukazują to Constitutiones Apostolorum, które są kompilacyjnym zbiorem przepisów liturgiczno-kanonicznych, jaki powstał ok. 380 roku w Antiochii Syryjskiej lub w Konstantynopolu. Zbiór ten jest najszerszym tego rodzaju dziełem, które wydała starożytność chrześcijańska. Będąc kompilacją, Constitutiones Apostolorum czerpią z wcześniejszych źródeł: księgi I-VI opierają się na Didascalia Apostolorum. Księga zaś VII może być podzielona na dwie części, z których pierwsza stanowi rozszerzoną naukę Didache, druga zaś zawiera przepisy i modlitwy odnoszące się do katechumenów i samego obrzędu chrztu. Księga VIII natomiast ma swoje źródło w Traditio Apostolica św. Hipolita Rzymskiego. Jest ona dla nas najważniejsza, gdyż zawiera obrzęd udzielania różnych święceń. Kończy się zaś 85 Kanonami Apostolskimi ${ }^{28}$. Na podstawie Constitutiones Apostolorum można zauważyć znaczny postęp interesującego nas zagadnienia w stosunku do źródel, $\mathrm{z}$ których one czerpią.

W Constitutiones ustala się między innymi przepisy dotyczące specjalnego ordo wdów. Mają one mieć przynajmniej 60 lat $^{29}$, podobnie jak to ustala św.

${ }^{25}$ Por. tamże I 40, ed. Rahmani s. 97: „Exhortetur mulieres inobedientes, erudiat ignorantes, reas convertat, doceatque illas, ut sint pudicae, diaconissasque perquirat. Quae introeunt, efficiat ut sciant, quomodo et quaenam ipsae esse debeant; et quae extra manent, adhortetur. Eis, quae audiunt, consilium patienter praebeat de iis, quae bona sunt. Inobedientes post tres admonitiones non alloquatur. Foveat illas, quae cupiunt esse in virginitate vel puritate. Corripiat modeste et pacate sese exhibentes ex adverso. [...]. Superflua et vana loquentes privatim reprehendat [...]. [...] visitet aegrotas [...]".

${ }^{26}$ Por. tamże II 4, ed. Rahmani s. 119: „Mulieres in ecclesia stent modeste et scienter: secus a viduis habentibus praecedentiam sessionis admoneantur".

${ }^{27}$ Por. tamże II 8, ed. Rahmani s. 129-131: „Mulieres [= baptizandae] a viduis habentibus praecedentiam sessionis, cum presbyter recitat super illas [formulam]. Item in collatione baptismi aeaedem viduae intra velum teneant mulieres obducto velo, cum episcopus profert formulas professionis; itemque dum profert formulas abrenuntiationis".

${ }^{28}$ Por. Degórski, Liturgiczna poshuga kobiet..., art. cyt., s. 46.

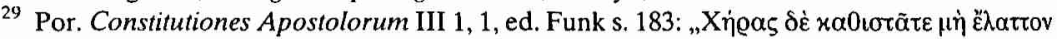

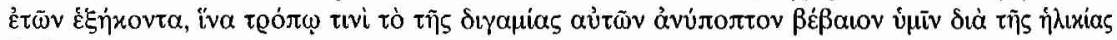

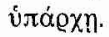


Pawel (por. 1Tm 5, 9). Wydaje siç, że użyteczność posługi wdów we wspólnocie kościelnej zmniejsza się, gdyż nie są już wymieniane wraz z męskimi członkami hierarchii, jak to miało miejsce jeszcze choćby w Didascalia, gdzie czytamy, iż ani biskup, ani kapłan, ani diakon, ani wdowa nie mogą wypowiadać przekleństwa $^{30}$. Przepis ten w Constitutiones został bowiem zastąpiony następującym zwrotem:

„Ani biskup, ani kapłan, ani diakon, ani żaden inny czlonek duchowieństwa [...]”31.

Innym świadectwem rozwoju instytucji wdów - czy, ogólnie rzecz ujmując, posługi kobiet - jest fakt, że mogą nie tylko nauczać podstawowych prawd wiary, jak to wymagała Didascalia, lecz także całości nauki chrześcijańskiej ${ }^{32}$. Mają to jednak czynić prywatnie, a nie oficjalnie podczas liturgicznego zgromadzenia w kościele:

„Nie pozwalamy, aby kobiety nauczały w kościele, lecz tylko, aby modliły się i słuchały nauczycieli" ${ }^{33}$.

Jeżeli chodzi o udzielanie sakramentu chrztu, to Constitutiones Apostolorum zabraniają czynienia tego kobietom, opierając się na argumentacji, którą już wcześniej stosowała Didascalia, według której, jeśli nasz Pan uważałby za stuszne, aby upoważnić także kobiety do udzielania sakramentu chrztu, to razem $\mathrm{z}$ apostołami posłałby w tym celu także i te święte niewiasty, które były z nimi bardzo związane. Co więcej, On sam dałby się ochrzcić przez najświętszą ze wszystkich ludzi - swoją Matkę ${ }^{34}$. Tak więc także i Constitutiones uważają szafarstwo sakramentu chrztu i spełnianie innych funkcji kultycznych za czynność czysto kapłańską ${ }^{35}$, co więcej - męską:

${ }^{30}$ Por. Didascalia Apostolorum III 11, 4-5, ed. Funk s. 208: „Procul ergo sint viduae a maledictionibus, quia ad benedicendum constitutae sunt. Itaque neque episcopus nec presbyter nec diaconus nec vidua maledictionem emittat ex ore suo".

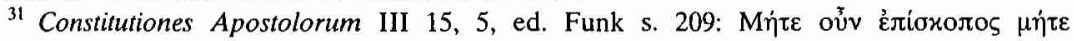

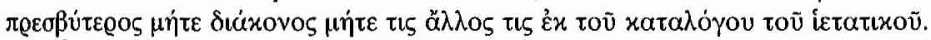

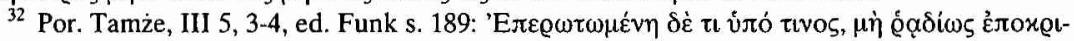

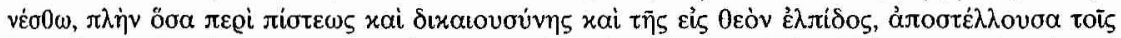

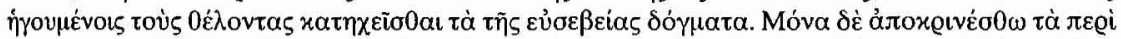

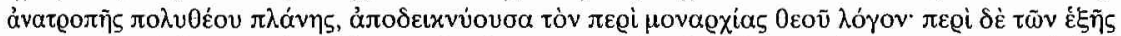

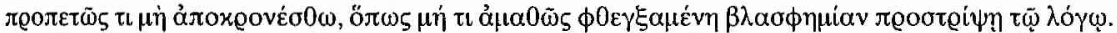

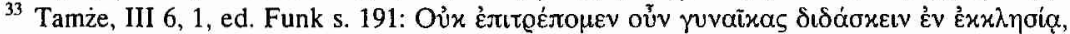

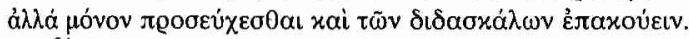

${ }^{34}$ Por. Didascalia III 9, 1-3, ed. Funk s. 198-200: „Mulierem aut baptizare vel a muliere baptizari non approbamus, quia hoc illegitimum est et magnum periculum ei, quae baptizat, et ei, qui baptizatur. Si enim liceret a muliere baptizari, profecto Dominus ac magister noster a Maria matre sua baptizatus fuisset; baptizatus est autem a Ioanne, sicut et alii e populo. Nolite igitur vobis periculum struere, fratres et sorores, conversantes praeter legem evangelii".

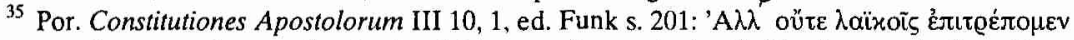

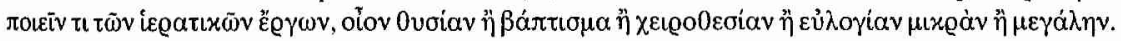


„[...] nie zalecamy robienia tego. Byłby to czyn niebezpieczny, co więcej - przeciwny prawu i bezbożny. Jeśli bowiem glową kobiety jest mężczyzna i to on wlaśnie jest przeznaczony do kapłaństwa, to nie byłoby rzeczą sluszną, odwracając porządek natury, pozostawiać glowę i udawać się w odwrotną stronę ciała [...]. [...] to wlaśnie bezbożna nieświadomość Greków skłania ich do święcenia kapłanek dla posługi względem bóstw kobiecych [...]"36.

Tego rodzaju norma-zakaz pozwala nam niewątpliwie sądzić, że we wspólnocie, dla której przepis ten został podany, znajdowały się kobiety, które udzielały tego sakramentu, a przynajmniej uważały, iż niewiasty mogą go szafować. Ostatnie zaś słowa, oskarżające pogańskich Greków o niewiedzę, zdają się świadczyć o powoływaniu się przez zwolenników udzielania chrztu przez kobiety, czy w ogóle sprawowania przez nie czynności kapłańskich, właśnie na ich przykład.

5. Posluga wdów w Kościele w Egipcie. Posługa kobiet w pierwotnym Kościele koptyjskim w Egipcie jest znana dzięki tzw. „Kanonom kościelnym świętych Apostołów”. Jest to dokument liturgiczno-prawny, który powstał w IV stuleciu. Za jego język oryginalny uchodzi greka. Posiadamy ponadto jego starożytne przekłady na język koptyjski, łaciński, syryjski, etiopski i arabski ${ }^{37}$. Dokument, jak na to wskazuje tytuł, chce być dzielem samych Apostołów, którzy - wierni woli Pana - kładą prawne podwaliny pod rodzący się Kościól. Dla naszego zagadnienia szczególnie ważne są kanony XV-XXI; one bowiem podają prawa dotyczące hierarchicznej struktury Kościoła, omawiając tematy dotyczące biskupów, kapłanów, diakonów, lektorów i wđów. Odnośnie do tych ostatnich, kanony postanawiają, iż w każdej wspólnocie kościelnej mają być trzy wdowy. Liczba ta jest wymagana także, jeżeli chodzi o diakonów i kapłanów (biskup oczywiście ma być jeden). Te trzy wdowy nie mają jednak do spełnienia tych samych zadań. Pierwsze dwie bowiem spełniają funkcje o charakterze prorockim, na wzór Anny, córki Fanuela z pokolenia Asera (por. Łk 2, 36): mają modlić się za wszystkich, którzy poddani są jakiejkolwiek próbie czy cierpieniu, oraz aby Pan objawił to, co jest konieczne ${ }^{38}$. Posługa ich jest więc duchowo-kontemplacyjna. Trzecia zaś z tych wdów ma spełniać obowiązki, które w prawodawstwie owego okresu przypisywane bywały w innych

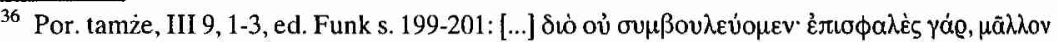

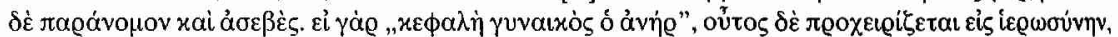

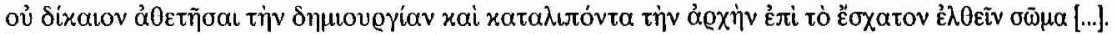

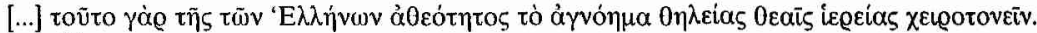

${ }^{37}$ Por. Degórski, Liturgiczna postuga kobiet..., art. cyt., s. 55.

${ }^{38}$ Por. Canones Apostolorum ecclesiastici 21, 1, ed. T. Schermann: Die allgemeine Kirche. nordnung des 2. Jahrhunderts. Frühchristliche Liturgien und kirchliche Überlieferung, Paderborn

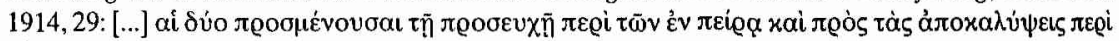
ở ờ $\delta \dot{\varepsilon} \eta$. 


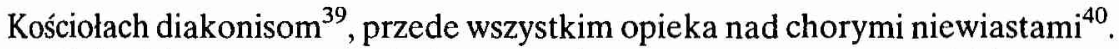
Jeżeli chodzi o wymagania, jakie się stawia tym wdowom, to oczywiście pozostają tu nadal aktualne normy ogólne dotyczące diakonów jako takich z $1 \mathrm{Tm} 3$, 8. Ponadto „Kanony kościelne świętych Apostołów” żądają, aby wdowa byla:

„trzeźwą, niech informuje kapłanów o tym, co konieczne, niech ucieka od niegodziwego zysku, niech będzie umiarkowana względem wina, aby mogla czuwać podczas nocnych posług i wypełnić inne dobre dzieła, które by chciała" ${ }^{41}$.

Norma ta nie wspomina więc o jakiejkolwiek posłudze liturgicznej wdów, a w szczególności o takiej, która wiązałaby się z szafowaniem sakramentu eucharystii. Co więcej, dokument wprost to wyklucza w kanonach XXIV$\mathrm{XXVIII}^{42}$, wkładając w usta św. Jana Apostoła argumentację przemawiającą za takim stanowiskiem:

„Zapomnieliście, bracia, że Mistrz - gdy poprosil o chleb i kielich i je pobłogosławił, mówiąc: To jest moje ciało i krew - nie pozwolił im [= kobietom], aby stały wraz z nami, ${ }^{43}$.

6. Wdowy w Kościele Rzymu i w Italii. Pochodzący z 251 lub 253 roku list papieża Korneliusza do Fabiusza z Antiochii - podobnie jak zresztą Hipolitowa Traditio Apostolica - nie wspomina w ogóle jakiejkolwiek posługi kościelnej kobiet, gdy przedstawia strukturę Kościoła Rzymskiego. Tak oto brzmi odpowiedni fragment listu, zachowany u Euzebiusza z Cezarei:

„Czyż więc nie wiedzial obrońca Ewangelii, że w Kościele katolickim jest tylko jeden biskup? Wiedział także [...], że jest w nim czterdziestu sześciu prezbiterów, siedmiu diakonów, siedmiu subdiakonów, czterdziestu dwóch akolitów, pięćdziesięciu dwóch egzorcystów, lektorów i ostiariuszy, ponad tysiąc pięćset wdów i ubogich" ${ }^{, 4}$.

${ }^{39}$ Posługa diakonis w Kościele w Egipcie nie była znana. Mogą o tym świadczyć powstałe w Aleksandrii między 336 a 340 rokiem tzw. «Kanony» Hipolita. W dokumencie tym bowiem nie znajdujemy żadnej nawet wzmianki o diakonisach, aczkolwiek jest tu mowa o udzielaniu chrztu i lączącej się z tym trosce o zachowanie przyzwoitości ze względu na koniecznośc obnażania się osób, które go przyjmują, por. R.G. Coquin, Les Canons d'Hippolyte, édition critique de la version arabe, introduction et traduction française [= PO 31, 2], Paris 1966.

${ }^{40}$ Por. Canones Apostolorum ecclesiastici 21, 2, ed. Schermann s. 29: [...] $\mu i \alpha \delta \dot{\varepsilon} \pi \alpha \varrho \varepsilon \delta \varrho \varepsilon v ́$ -

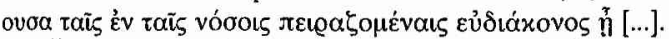

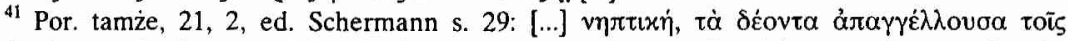

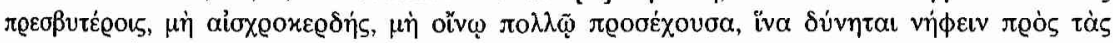

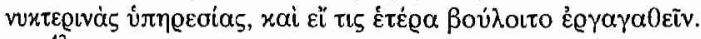

42 Por. tamże, 24-28, ed. Schermann s. 31-33.

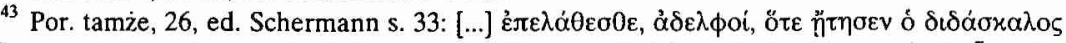

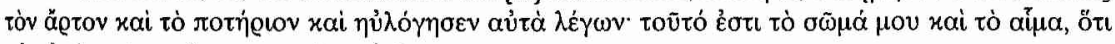

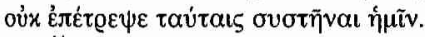

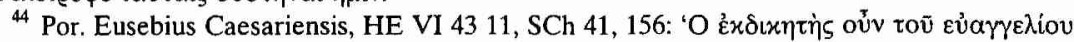

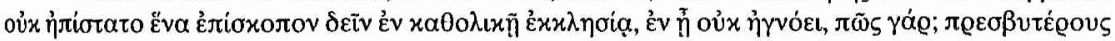


Nie ma więc tu w ogóle mowy chociażby o diakonisach. Wspomniane natomiast wraz z ubogimi wdowy wydają się być jedynie szczególną, uprzywilejowaną kategorią w Kościele Rzymskim (jego prawdziwym bogactwem), będącą przedmiotem osobliwej troski ze strony biskupa i duchowieństwa.

O wdowach wspominają teksty liturgiczne. Tak bowiem modlił się Kościól Rzymski:

„Módlmy się za wszystkich biskupów, prezbiterów, diakonów, akolitów, egzorcystów, lektorów, ostiariuszów, wyznawców, dziewice, wdowy i za cały święty lud Boży"45.

7. Wdowy w Galii i na Półwyspie Iberyjskim. Podobną sytuację - charakteryzującą się niechęcią względem dopuszczania kobiet do kościelnych posług liturgicznych - spotykamy także w Galii i na Półwyspie Iberyjskim. Przyczyny takiego stanu rzeczy należy niewątpliwie szukać w chęci przeciwstawienia się prawowiernego Kościoła ruchom charyzmatyczno-heretycko-schizmatyckim (wymieńmy tu choćby montanizm czy pryscylianizm), które pojawiały się na tych terenach, a w których kobiety odgrywały ważną rolę.

Zagadnieniem dopuszczania kobiet do sprawowania funkcji liturgicznych zajął się między innymi Synod w Nîmes z 394 lub 396 roku. Zgromadził on około dwudziestu biskupów. Wszyscy oni byli zwolennikami antypryscylianisty Feliksa $z$ Trewiru. Jako tacy chcieli rozwiązać problemy doktrynalne związane $z$ rozszerzającym się pryscylianizmem, oraz zażegnał waśnie powstałe pomiędzy biskupami z Aix i z Arles oraz biskupami Marsylii i Vienny. Nieobecność jednak przeciwników nie pozwoliła na rozwiązanie tych trudności. Synod uchwalił jednak wiele kanonów dyscyplinarnych zwróconych w szczególności przeciwko włóczęgostwu duchowieństwa i udzielaniu kobietom święceń diakonatu. Przepisy te - szczególnie w ostatnim przypadku - podyktowane były, jak już powiedzieliśmy, chęcią przeciwstawienia się pojawiającym się sektom szczególnie pryscylianom ${ }^{46}$.

Sam już zakaz udzielania święceń diakonatu kobietom świadczy niewątpliwie, że ich udzielano. Synod w Nîmes, zakazując czynienia tego, uważa, że nie jest to zgodne $z$ nauką apostołów i tradycją Kościoła. Potępia więc możliwość udzielania kobietom takowych święceń jako rzecz nigdy nie istniejącą wcześ-

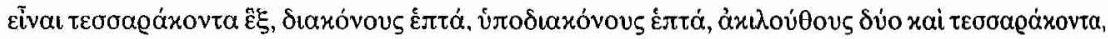

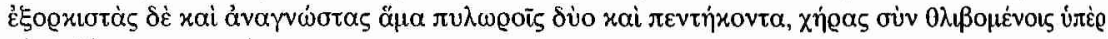

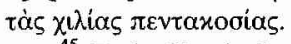

45 P. de Clerck, La prière universelle dans les liturgies latines anciennes, Münster 1977, 136: „Oremus pro omnibus episcopis, presbyteris, diaconibus, acolythis, exorcistis, lectoribus, ostiariis, confessoribus, virginibus, viduis et pro omni populo sancto Dei"; por. także Degórski, Liturgiczna posluga kobiet..., art. cyt., s. 61-62.

${ }^{46}$ Por. Degórski, Liturgiczna postuga kobiet..., art. cyt., s. 62-63. 
niej, bezmyślną, niegodziwą, która - jako taka - nie może być przyjęta przez Kościól ${ }^{47}$.

Także i Kościół w Hiszpanii nie dopuszcza spełniania funkcji lektorki czy diakonisy, widząc tu zagrożenie ze strony wrogich sekt. Chodzi przede wszystkim o przeciwstawienie się rozwijającym się na tych terenach pryscylianistom. Taka niewątpliwie była intencja synodu w Saragossie z 380 roku. Synod ten zgromadził dwunastu biskupów $\mathrm{z}$ różnych prowincji kościelnych Hiszpanii i kilku z Akwitanii, aby przeciwstawić się pryscylianizmowi. Uczynił to w ośmiu kanonach, potępiając heretycką naukę tejże sekty, nie wymieniając jednak konkretnych heretyków. Już pierwszy z ośmiu kanonów przestrzega katoliczki przed uczestnictwem w zgromadzeniach pryscylianistów pod pretekstem uczenia się czy też wykonywania jakiejś posługi kościelnej ${ }^{48}$.

Tego rodzaju troska Kościoła Hiszpanii przejawia się także w uchwałach późniejszych synodów; tak na przykład I synod w Toledo (7 IX 400) zobowiązał zakonnice i wdowy do czytania lucernarium ${ }^{49}$ jedynie w kościele lub in villa, to znaczy - wylącznie w sposób oficjalny, w obecności przedstawiciela hierarchii kościelnej: biskupa, prezbitera lub diakona ${ }^{50}$.

Idąc dalej, spotykamy tzw. Statuta Ecclesiae antiqua, zebrane ok. 475 r. przez Gennadiusza z Marsylii, które - powtarzając uchwały IV synodu w Kartaginie z dnia 26 października 398 roku $^{51}$ - precyzują, iż kobiety nie mogą uczyć mężczyzn podczas zgromadzeń liturgicznych i udzielać chrztu. Pozwala się

${ }^{47}$ Por. Concilium Nemausense can. 2, CCL 148, 50: „Illud enim a quibusdam suggestum est, ut contra apostolicam disciplinam, incognito usque in hoc tempus, in ministerium feminae, nescio quo loco, leviticum videantur adsumptae: quod quidem, quia indecens est, non admittit ecclesiastica disciplina, et contra rationem facta, talis ordinatio distruatur: providendum ne quis sibi hoc ultra praesumat".

${ }^{48}$ Por. Concilium Caesaraugustanum (a. 380), can. 1, ed. J. Vives: Concilios visigóticos e hispano-romanos, Barcelona-Madrid 1963,16: „Ut mulieres omnes catholicae et fideles a virorum alienorum et coetibus separentur, vel ad ipsas legentes aliae studio vel docendi vel discendi conveniant, quoniam hoc apostolus iubet. $\mathrm{Ab}$ universis episcopis dictum est: anathema futuros qui hanc concilii sententiam non observaverint".

49 Jest to pierwsza częś́ oficjum wieczornego, por. np.: Isidorus Hispalensis, Regula monachorum 6.

${ }^{50}$ Por. Concilium Toletanum I (a. 400), can. 9, ed. J.D. Mansi: Sacrorum Conciliorum nova et amplissima collectio, III, Florentiae 1759, 1000: „Nulla professa, vel vidua, absente episcopo vel presbytero, in domo sua antiphonas cum confessore, vel servo suo faciat: lucernarium vero, nisi in ecclesia, non legatur, aut si legitur in villa, praesente episcopo vel presbytero vel diacono, legatur". Na temat tegoż kanonu por. B. Degórski, Peculiarità nel monachesimo del Mediterraneo latino secondo $i$ concili dei secoli $I V-V I$, w: Cristianesimo e specificità regionali nel Mediterraneo latino (sec. IV.VI). XXII Incontro di studiosi dell'antichità cristiana. Roma, 6-8 maggio 1993 [= Studia Ephemeridis Augustinianum, 46], Roma 1994, 96.

${ }^{51}$ Por. Concilium Carthaginense IV (26 X 398), can. 12, CCL 149, 345: „Viduae uel sanctimoniales quae ad ministerium baptizandarum mulierum eliguntur, instructae sint ad officium, ut possint aperto et sano sermone docere imperitas et rusticas mulieres tempore quo baptizandae sunt, qualiter baptizatori ad interrogata respondeant, et qualiter accepto baptismate uiuant". 
jedynie wdowom i zakonnicom przygotowywać proste, wiejskie kobiety do chrztu, katechizując je, w jaki sposób należy wieść życie chrześcijańskie po przyjęciu tegoż sakramentu ${ }^{52}$.

W tym samym czasie przeciwko diakonatowi kobiet wypowiada się dnia 15 września 517 r. synod z Épaone w Burgundii, powtarzając wcześniejsze zarządzenie synodu $z$ Orange. W 516 bowiem roku na tron Burgundii wstapil nawrócony na wiarę katolicką arianin Zygmunt. Od tego czasu zwolennicy Ariusza zostali na tych terenach pokonani. W 517 r. w Épaone zebral się właśnie synod, w którym wzięło udział trzech metropolitów, dwudziestu jeden biskupów, jeden prezbiter jako delegat pewnych prowincji kościelnych, duchowieństwo i znaczniejsi przedstawiciele laikatu. Synod ogłosil czterdzieści kanonów, z których ostatni stanowi niejako konkluzję. W kanonach 29 i 31 synod odwołuje się do poprzednich praw. Ponadto widoczne są liczne podobieństwa pomiędzy kanonami 10,23 i 32 tegoż synodu, a kanonami 11,13 i 22 narodowego synodu Franków, który odbył się dnia 10 lipca 511 r. w Arles. Niemniej jednak widoczne są także różnice i innowacje pomiędzy dekretami obydwu synodów. Dla przykładu: pomiędzy kanonami 3, 10 i 25 synodu w Arles, a kanonami 39, 33 i 35 synodu w Épaone. Z tego to powodu nie można wskazywać na bezpośredni wplyw synodu z Arles z 511 r. na synod w Épaone. Ponadto, żaden $z$ biskupów nie uczestniczył w obydwu synodach. Synod w Épaone z 517 r. odrzuca święcenie diakonis jako niezgodne z tradycją Kościoła łacińskiego, który zna jedynie udzielanie specjalnego błogosławieństwa wdowom, które pragną wieść żywot samotny jako conversae, będąc na specjalnej służbie Kościoła. Aprobuje ponadto stan dziewic konsekrowanych, których zewnętrznym znakiem jest velatio ${ }^{53}$.

Jak można się zorientować z powyżej przedstawionego materiału i analizowanych źródeł, w okresie patrystycznym - jeżeli chodzi o Wielki Kościól spotykamy świadectwa mówiące o sprawowaniu przez wdowy posług liturgicz-

$\$ 2$ Por. Statuta Ecclesiae antiqua. Concilium Carthaginense IV (26 X 398), can. 100, CCL 148, 184: „Viduae uel sanctimoniales quae ad ministerium baptizandarum mulierum eliguntur, instructae sint ad officium, ut possint aperto et sano sermone docere imperitas et rusticas mulieres tempore quo baptizandae sunt, qualiter baptizatori ad interrogata respondeant, et qualiter accepto baptismate uiuant". Na temat tego kanonu por. Degórski, Peculiarità nel monachesimo ..., art. cyt., s. 95-96.

${ }^{53}$ Por. Concilium Epaonense (15 IX 517), can. 21, CCL 148/A, 29: „Viduarum consecrationem, quas diaconas vocitant, ab omni regione nostra penitus abrogamus, sola eis paenitentiae benedictione si converti ambiunt, imponenda". W kanonie 20 synodu w Tours z 567 r. (por. CCL 148/A, 184) diakonisą jest nazwana żona diakona. Świadczyć to może, iż stopniowo praktyka spełniania przez kobiety posługi diakońskiej wychodzi z użycia. 
no-kościelnych. Bardzo natomiast rzadkie są wzmianki odnoszące się do wykonywania przez nie posług czysto kapłańskich (prezbiterskich). Ponadto nie spotykamy $\mathrm{w}$ ogóle świadectw mówiących o sprawowaniu przez niewiasty lektoratu, akolitatu czy subdiakonatu. Mamy tu na myśli, jak powiedzieliśmy, oficjalne posługi zaaprobowane przez Wielki Kościól, gdyż, jak widzieliśmy, w rzeczy samej tego rodzaju posługi były nieoficjalnie sprawowane przez kobiety.

Jeżeli chodzi o Kościół Zachodni, to od samego początku odrzucał on możliwość spełniania przez kobiety jakiejkolwiek posługi liturgiczno-kościelnej. Przyczynę tego należy widzieć w chęci przeciwstawienia się rozbijającym Kościół sektom błędnowierczym (szczególnie gnostykom, montanistom czy pryscylianistom), które pozwalały kobietom sprawować na równi z mężczyznami różne posługi kościelne. $\mathrm{Z}$ tego więc powodu Kościół Zachodni w swoim prawodawstwie (przynajmniej od IV wieku, gdyż począwszy od tego czasu zachowały się dokumenty kanoniczne na ten temat) stale przeciwstawiał się spełnianiu przez kobiety liturgicznej posługi (szczególnie diakońskiej). Widać to dobrze na podstawie uchwal synodalnych szczególnie Kościoła Galii i Hiszpanii.

Jeżeli zaś chodzi o liturgiczną posługę wdów czy w ogóle kobiet w Kościele Wschodnim, to świadectwa o tym spotykamy począwszy już od III wieku. Nie należy jednak wyciągać $\mathrm{z}$ tego wniosku, iż ta forma kobiecej posługi w Kościele pojawiła się właśnie w tym okresie (w III w.), gdyż musimy wziąć pod uwagę fakt, iż posiadamy względnie mało dokumentów z I czy II wieku, które dotarły do naszych czasów. Należy ponadto pamiętać o wielkiej roli, jaką w pierwotnym Kościele posiadała nieprzerwana tradycja sięgająca samego Chrystusa i apostołów. Co więcej, nie wolno zapominać, iż dla ludzi żyjących w starożytności jakakolwiek nouitas czy nouum skazane było nieodzownie na odrzucenie jako zgoła bezwartościowe, gdyż przeciwne bezcennemu mos maiorum.

Zadania liturgiczne sprawowane przez kobiety były różne w różnych epokach i na różnych obszarach geograficznych: przygotowywały do chrztu dorosłe kobiety; namaszczały je przed i po jego przyjęciu; przyjmowały uroczyście neofitki; opiekowały się nimi i katechizowały, starając się, aby wiodły życie zgodne $z$ Ewangelią; strzegły drzwi kościoła $\mathrm{i}$ dbały, aby panował porządek podczas liturgii, a w świątyni i prezbiterium panowała czystość i ład; udzielaty niekiedy eucharystii kobietom czy małym dzieciom; modliły się w sposób szczególny za wspólnotę kościelną; sprawowały opiekę nad chorymi kobietami, niekiedy nawet namaszczając je (sakrament chorych?!); przygotowywaly zmarłe na pogrzebanie; przewodniczyły modlitwie liturgicznej Kościoła, czytając w żeńskich wspólnotach mniszych nawet Ewangelię pod nieobecność prezbitera czy diakona; spełniały niekiedy funkcję doradcy samego biskupa.

$\mathrm{Z}$ biegiem jednak czasu - szczególnie $\mathrm{z}$ powodu wchodzenia zwyczaju udzielania chrztu niemowlętom $i$, co się z tym łączy, zaniechania chrzczenia 
dorosłych - posługa liturgiczna wdów czy kobiet jako takich straciła swój główny cel istnienia: pomoc przy udzielaniu chrztu dorosłym niewiastom. $\mathrm{Z}$ tej to przyczyny tytuł i zadania spełniane przez nie przeszły na przełożone klasztoru, gdyż teraz one będą otaczały troską Najświętszy Sakrament, rozdzielając go chorym współsiostrom oraz przewodniczyły liturgii godzin, odczytując Ewangelię i inne teksty liturgiczno-sakralne.

\section{LE VEDOVE NELL'ANTICHITÀ CRISTIANA \\ E IL LORO MINISTERO NELLA CHIESA}

(Riassunto)

L'articolo sviluppa un'indagine storico-teologica sulla figura e sulla ministerialità della vedova nella Chiesa primitiva, anche sullo sfondo dell'attuale problema dogmatico-ecumenico del sacerdozio femminile. In particolare, sono stati presi in considerazione i seguenti temi: il ministero pastorale delle vedove nei secoli II e III, nella Siria Orientale, nelle Chiese monofisite, nella Chiesa bizantina,nella Chiesa in Egitto, nella Chiesa romana, della Gallia della Spagna. 